\title{
Will global change modify the distribution of the Anadenanthera colubrina (Fabales: Fabaceae) plant, a key species in dry tropical forest?
}

\author{
Eugenia M. Giamminola ${ }^{1 *}$, María M. Urtasun ${ }^{1,2}$, Carola Y. Lamas ${ }^{1,2} \&$ Marta L. de Viana $^{1}$ \\ 1. Banco de Germoplasma de Especies Nativas- Instituto de Ecología y Ambiente Humano - Universidad Nacional de \\ Salta. Av. Bolivia (5150), Salta (CP 4400), Argentina; eugeniagiamminola@gmail.com, mmurtasun@gmail.com, \\ carolalamas14@hotmail.com,mldeviana@yahoo.com.ar \\ 2. Consejo Nacional de Investigaciones Científicas y Técnicas (CONICET), Universidad Nacional de Salta, Av. Bolivia \\ (5150), Argentina. \\ * Correspondence
}

Received 08-I-2020. Corrected 17-II-2020. Accepted 04-III-2020.

\begin{abstract}
Introduction: Seasonally dry tropical forests (SDTF) are one of the most threatened terrestrial ecosystems on the planet as a consequence of global change. They harbor high biodiversity and provide a wide range of ecosystem services; therefore, their conservation is a priority worldwide. Climate warming, as well as land use patterns, are leading to species distribution range shifts. Objective: The objective of this work was to study the current and future potential distribution of a SDTF representative tree species (Anadenanthera colubrina) in the Argentinian Sub Andean Piedmont nucleus and to assess the effects of land use and climate changes. Methods: Current and future potential distribution was modeled with Maxent, using 49 presence points and 20 variables. Climate change effects were estimated in four different temperature and carbon dioxide concentration scenarios. Land use changes were determined subtracting the deforested area until 2017 to the current and future potential distribution of the species. Results: A. colubrina current distribution represents $18 \%$ of Northwestern Argentina. Land use changes decreased almost $25 \%$ of it and climate change will probably cause a retraction in the East and a slight expansion towards the West and South of the current distribution. The synergistic effect of land use and climate change projected to the worst scenario would reduce $63 \%$ of its current distribution. Conclusions: Our data demonstrate the central role of distribution range studies to assess the effects of anthropic activities. Climate change and land use change would have a negative and synergistic effect on the distribution of A. colubrina. Although a possible expansion of the Sub Andean Piedmont nucleus of SDTF would occur, this expansion may be limited by the Sub Andean mountain range that could act as an orographic barrier.
\end{abstract}

Key words: climate change, conservation, geographic range, land use change, species distribution models.

Giamminola, E.M., Urtasun, M.M., Lamas, C.Y. \& de Viana, M.L. (2020) Will global change modify the distribution of the Anadenanthera colubrina (Fabales: Fabaceae) plant, a key species in dry tropical forest? Revista de Biología Tropical, 68(2), 517-527.

Climate warming and land use change are the main processes leading biodiversity loss and species range shifts (Travis, 2003; Ceballos \& Ortega-Baes, 2011). Seasonally dry tropical forests (SDTF) are of high conservation value because they harbor a great biodiversity and they provide numerous environmental goods and services important for the survival and wellness of humanity (Portillo-Quintero,
Sanchez-Azofeifa, Calvo-Alvarado, Quesada, \& do Espirito-Santo, 2015; Sunderland et al., 2015). They occur in tropical and subtropical regions, with high precipitation (700-2000 $\mathrm{mm} /$ year) and a markedly dry season. Nearly $42 \%$ of the world tropical forests are seasonally dry and $54 \%$ of them are located in South America. North and Central America, Africa and Eurasia share the remaining area. SDTF 
are among the most threatened tropical ecosystems, and are being affected by global change; thus, their conservation is a priority (Trejo \& Dirzo, 2000; Miles et al., 2006; Rudel, 2017). For example, Portillo-Quintero and SánchezAzofeifa (2010) showed that two-thirds (60 $\%)$ of tropical dry forest in South America has already been converted, and that in some countries the conversion rate reached $95 \%$. In the Northwest of Argentina, the SDTF occur in Yungas and Chaco Serrano ecoregions, where deforestation, degradation and fragmentation are the dominant processes of land use changes (de Viana \& Morales Poclava, 2010). Recently, Leake, López, \& Leake (2016) reported the conversion of 1.25 million ha of Argentinean Chaco forest in agricultural land.

Climate change also has and will continue to play an important role in land cover and land use dynamics as well as on species range shifts (Aide et al., 2019). Warming heat waves, drought, floods, fires, storms, sea level rise are expected for the near future and extreme precipitation events over most of Southeastern South America and Western Amazonia (Marengo, Jones, Alves, \& Valverde, 2009; IPCC, 2013). Similar trends are expected in Argentina for the next decades, with higher temperatures in the North and West than in the South and East of the country $\left(2-3{ }^{\circ} \mathrm{C}\right.$ vs. $\left.1-2{ }^{\circ} \mathrm{C}\right)$ especially during summer. In addition, an increase in precipitation is also projected for the North and Center regions (Barros et al., 2015). These conditions could probably cause a migration of SDTF to new areas that are currently occupied by tropical forest and savannas (Miles et al., 2006; Marengo et al., 2009; Rodrigues, Silva, Eisenlohr, \& Schaefer, 2015).

Species distribution models (SDMs) are widely used in ecology for generating hypothesis about the potential consequences of climate and land cover changes on the natural distribution of species (Guisan \& Thuiller, 2005; Elith \& Graham, 2009; Qin et al., 2017; Benito-Garzón, Alía, Robson, \& Zavala 2019). SDMs are correlational models of low structural complexity that rely on the statistical relationship between species occurrence and local climate. In the last decade, SDMs have been successfully used to define priority areas for conservation, restoration (Perosa et al., 2014) and to evaluate the effects of climate change on species distribution (Cruz-Cárdenas et al., 2016).

Anadenanthera colubrina (Vell) (Fabaceae) is a native tree species of wide distribution in South America and it is considered one of the most representative species of the SDTF. It is found in Brasil, Paraguay, Bolivia and Argentina from 100 to $2000 \mathrm{~m}$ above sea level (ma.s.l.). Its distribution encompasses four nuclei: 1- Caatinga (Northeast of Brasil), 2- Misiones (Northeast of Argentina, East of Paraguay, and Southwest of Brasil), 3- Chiquitanía (Southeast of Bolivia and North of Paraguay) and 4- Sub Andean Piedmont (Southeast of Bolivia and Northwest of Argentina) (Fig. 1) (Prado, 2000; Rodrigues et al., 2015; Mogni, Oakley, Maturo, Galetti, \& Prado, 2015). Despite its wide distribution, land use changes are causing populations fragmentation and local extinctions (Perea, Pedraza, \& Luceros, 2007). A. colubrina is considered a sacred tree and has been used for more than 3000 years in rituals and popular medicine due to the seed's alkaloids. The wood is of high quality and has many applications. In addition, it has a key role in restoration of degraded lands due to its high germination potential, fast growing, high regeneration speed and ability to fix atmospheric nitrogen (association with Rhizobium and other bacteria) (Demaio, Karlin, \& Medina 2002; Monteiro et al., 2006; Carod-Artal \& VásquezCabrera, 2007; Alibrandi et al., 2017; Ciaccio, Russo, Palla, Giamminola, \& de Viana, 2017).

The objective of this work was to study A. colubrina geographic distribution in the Argentinian Sub Andean Piedmont nucleus and to assess the effects of land use and climate change on the future distribution of the species.

\section{MATERIALS AND METHODS}

Study area: $A$. colubrina distribution was studied in the Sub Andean Piedmont nucleus which includes in Argentina the Northwestern provinces (Jujuy, Salta, Tucumán, Catamarca 


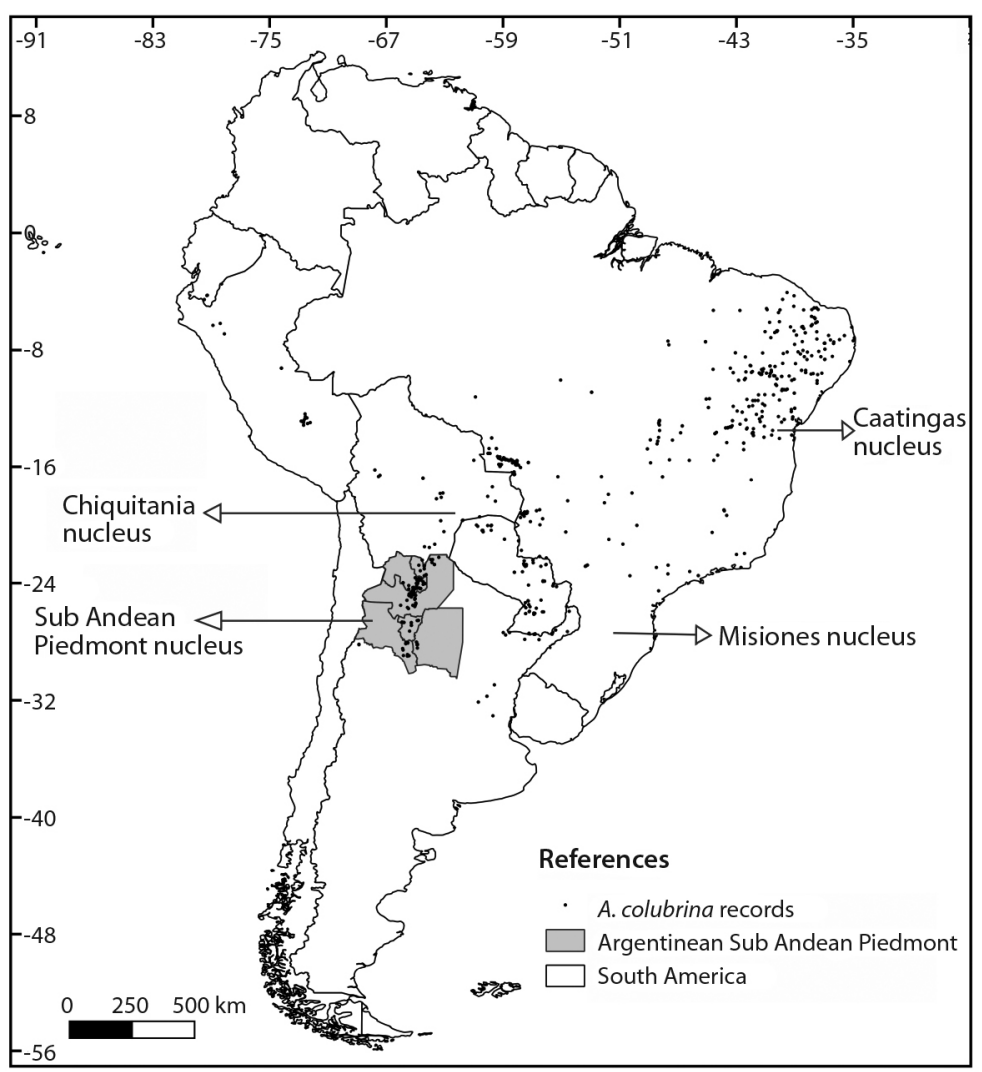

Fig. 1. Records of A. colubrina in South America (data GBIF, 2018).

and Santiago del Estero) (Fig. 1). This nucleus encompasses Yungas and Chaco ecoregions (Eastern Sub Andean slopes), occupies a wide altitudinal and latitudinal gradient (300 - 2000 m.a.s.l., 22 to $29^{\circ} \mathrm{S}$ ) and it represents the southernmost distribution of $A$. colubrina and of the STFD.

Species occurrence data: Occurrence records were obtained from the Native Species Gene Bank of the National University of Salta (de Viana \& Giamminola, 2018) and from the Global Biodiversity Information Facility (www.gbif.org). The data quality was controlled with Open Fine software: the incomplete data, duplicates and wrong coordinates were deleted (Verborgh \& De Wilde, 2013). This resulted in 49 presence points located in Northwestern Argentina, with a minimum distance of $2 \mathrm{~km}$ from each other to avoid the overfitting of the model.

Environmental variables: A total of 20 variables were used: nineteen bioclimatic downloaded from the WorldClim database (Hijmans, Cameron, Parra, Jones, \& Jarvis, 2005) and one topographic (elevation) with 30 seconds spatial resolution (Hijmans, Guarino, Cruz, \& Rojas, 2001). The effect of climate change on future distribution was modeled using the elevation and the same bioclimatic variables projected to the year 2050 for four future climate scenarios that differ in temperature and carbon dioxide levels: CC2.6, CC 4.5, CC 6.0 and CC8.5 (CCSM4) (Gent et al., 2011; IPCC, 2013). 
Species distribution model: Current and future distribution was estimated using Maxent version 3.4.1 (Phillips, Dudík, \& Schapire, 2020) and following the methodology proposed by Scheldeman \& Van Zonneveld (2011) and Phillips, Anderson, \& Schapired (2006). A total of ten runs were set for model building. The other values were kept as default. The Area Under the Receiver Operating Curve (AUC) was used to evaluate model's goodness-of-fit. AUC shows the sensitivity (true positive) versus the specificity (false positives) for every probability value predicted by the model. It varies from 0 to 1 indicating the model performance (Naoki, Gómez, López, Meneses, \& Vargas, 2006). Current and future potential distribution binary maps (presence/absence) were obtained using a presence probability threshold of 0.36 (10 percentile training presence) and were overlapped to identify three categories (Scheldeman \& Van Zonneveld, 2011): 1) Stable areas: low impact areas where the climatic conditions are currently adequate for the species and they would also remain in the future, 2) Expansion areas: new suitable areas, where the current climatic conditions are not adequate for the species, but they would be in the future and, 3) Retraction areas: high impact areas, where the current climatic conditions are suitable for the species, but they will support other vegetation types in the future.

Finally, the effects of land use changes were estimated by subtracting the deforested area of Yungas and Chaco ecoregions until 2017 to the current and future A. colubri$n a$ distribution (IDEASA, 2018). All analyses were accomplished using QGis 2.18.21 (QGIS Development Team, 2019).

\section{RESULTS}

Current potential distribution: $A$. colubrina distribution model was reliable, with high overall accuracy $(\mathrm{AUC}=0.88 \pm 0.066)$. The area with favorable environmental conditions for the establishment of $A$. colubrina represents $18 \%$ of northwestern Argentina $\left(61386 \mathrm{~km}^{2}\right)$. The model predicted a high occurrence probability in the Northeast of Salta province, East of Jujuy and Center of Tucumán, and a low occurrence probability in Catamarca and Santiago del Estero provinces (Fig. 2A). These results were consistent with our field observations.

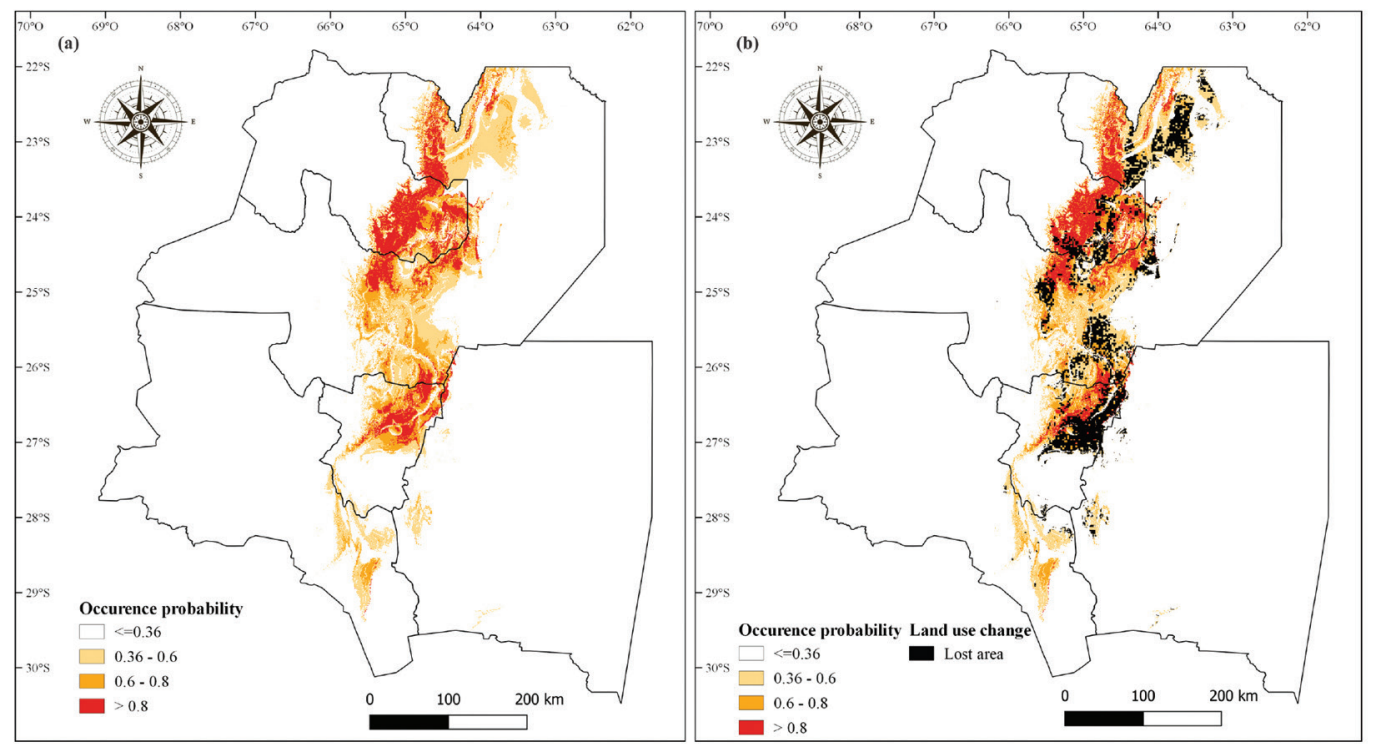

Fig. 2. A. A. colubrina current distribution and B. effect of land use change on A. colubrina current distribution. 
Distribution models under global change scenarios: Land use changes caused a loss in A. colubrina potential distribution range of $24.85 \%\left(15256 \mathrm{~km}^{2}\right)$. This loss affected regions with high and low occurrence probability, mainly in Jujuy, Salta and Tucumán provinces (Fig. 2B).

The effect of climate change on the distribution of the species varied between scenarios (Table 1). In the most optimistic scenario (CC2.6) a high percentage $(87 \%)$ of $A$. colubrina current distribution area would remain stable and a significant expansion would occur towards the East and Southwest of the current distribution. Conversely, in the remaining scenarios, only nearly half of the current distribution area would remain stable (42-54\%), the retraction area would be high (46 to $58 \%$ ), and the expansion would occur towards the West of its current distribution and would vary from 24 to $25 \%$ (Table 1, Fig. 3).

In addition, a significant loss in the stable area and an increase in the retraction area of all climate change scenarios were obtained when the synergic effect of land use changes and climate change was assessed. Finally, the expansion area would only be affected in the most optimistic scenario (Table 1, Fig. 4).

Overall, the Center of the Sub Andean Piedmont nucleus (East of Jujuy and Center of
Salta) was the most stable environment with low change probability. Therefore, the shifts would take place at the borders of the distribution range: the retraction would occur mainly in the East region and the expansion would be towards the West.

\section{DISCUSSION}

SDTF harbor high species diversity with many endemic and wide distribution species, thus, the study of species range shifts is a key topic for short, medium and long-term biodiversity conservation. Werneck, Costa, Colli, Prado, and Sites (2011) concluded that the present-day SDTF distribution is disjunctive, and it represents an expansion of an even more fragmented one during the Last Glacial Maximum. Since then, a progressive Southward and Eastward expansion of SDTFs range has occurred in coincidence with the warmer and wetter trend in climatic conditions. Nevertheless, at the beginning of the last century, a marked retraction began because of land use changes (agriculture, logging, urbanization, cattle grazing) (Trejo \& Dirzo, 2000; Miles et al., 2006). In this work, we obtained a $25 \%$ loss in A. colubrina distribution range (until 2017) as a consequence of land use changes

TABLE 1

Future distribution of $A$. colubrina under different climate change scenarios

\begin{tabular}{|c|c|c|c|c|c|}
\hline & \multirow{2}{*}{ Scenarios } & \multicolumn{4}{|c|}{ Distribution area $\left(\mathrm{km}^{2}\right)$} \\
\hline & & $\operatorname{cc} 26$ & $\operatorname{cc} 45$ & $\operatorname{cc} 60$ & $\operatorname{cc} 85$ \\
\hline \multirow[t]{6}{*}{ Climate change } & Stable areas & 53134 & 32969 & 31958 & 25730 \\
\hline & & $(87 \%)$ & $(54 \%)$ & $(52 \%)$ & $(42 \%)$ \\
\hline & Retraction areas & 8252 & 28417 & 29427 & 35655 \\
\hline & & $(-13 \%)$ & $(-46 \%)$ & $(-48 \%)$ & $(-58 \%)$ \\
\hline & Expansion areas & 48932 & 14714 & 15645 & 15227 \\
\hline & & $(+80 \%)$ & $(+24 \%)$ & $(+25 \%)$ & $(+25 \%)$ \\
\hline \multirow{6}{*}{$\begin{array}{l}\text { Synergistic effect } \\
(\mathrm{CC}+\mathrm{LUC})\end{array}$} & Stable areas & 39391 & 27829 & 27219 & 22541 \\
\hline & & $(64 \%)$ & $(45 \%)$ & $(44 \%)$ & $(37 \%)$ \\
\hline & Retraction areas & 21453 & 33554 & 34165 & 38842 \\
\hline & & $(-35 \%)$ & $(-55 \%)$ & $(-56 \%)$ & $(-63 \%)$ \\
\hline & Expansion areas & 38564 & 13589 & 14350 & 14480 \\
\hline & & $(+63 \%)$ & $(+22 \%)$ & $(+23 \%)$ & $(+24 \%)$ \\
\hline
\end{tabular}

In parentheses is the percentage with relation to the current area of distribution. $\mathrm{CC}=$ climate change, $\mathrm{LUC}=$ land use change. 


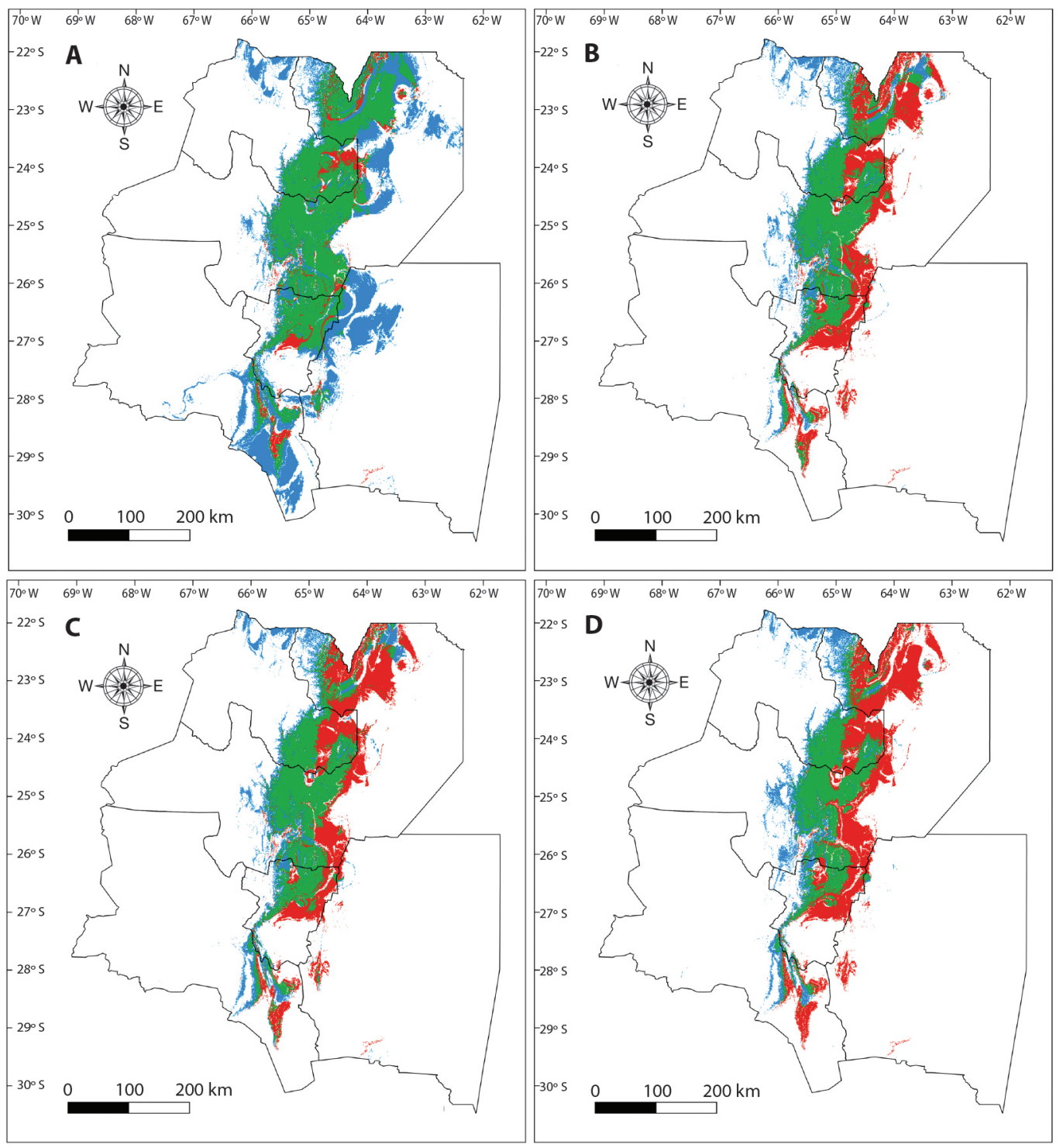

Fig. 3. Effect of climate change on A. colubrina future distribution, A. scenario CC2.6, B. scenario CC4.5, C. scenario CC6.0 and D. scenario CC8.5. Green: stable areas, red: retraction areas, and blue: expansion areas.

(LUC). If this trend continues in the future, the total loss of Sub Andean Piedmont nucleus will occur between the years 2050 - 2100 (Paruelo, Guerschman, \& Verón, 2005).

In addition, climate change (CC) will also cause species range shifts. For example, tree species of the Brazilian SDTF (A. colubrina, Aspidosperma pyrifolium and Myracrodruon urundeuva) are expected to expand its range towards savanna and humid forest areas by 2080 (Rodrigues et al., 2015). Similar results were obtained in this work: a possible expansion of A. colubrina distribution area towards the South and West of Northwestern Argentina. Although this expansion seems not to be limited by changes in land use, mountains could act as orographic barriers and limit the expansion. Land use changes, the main cause 


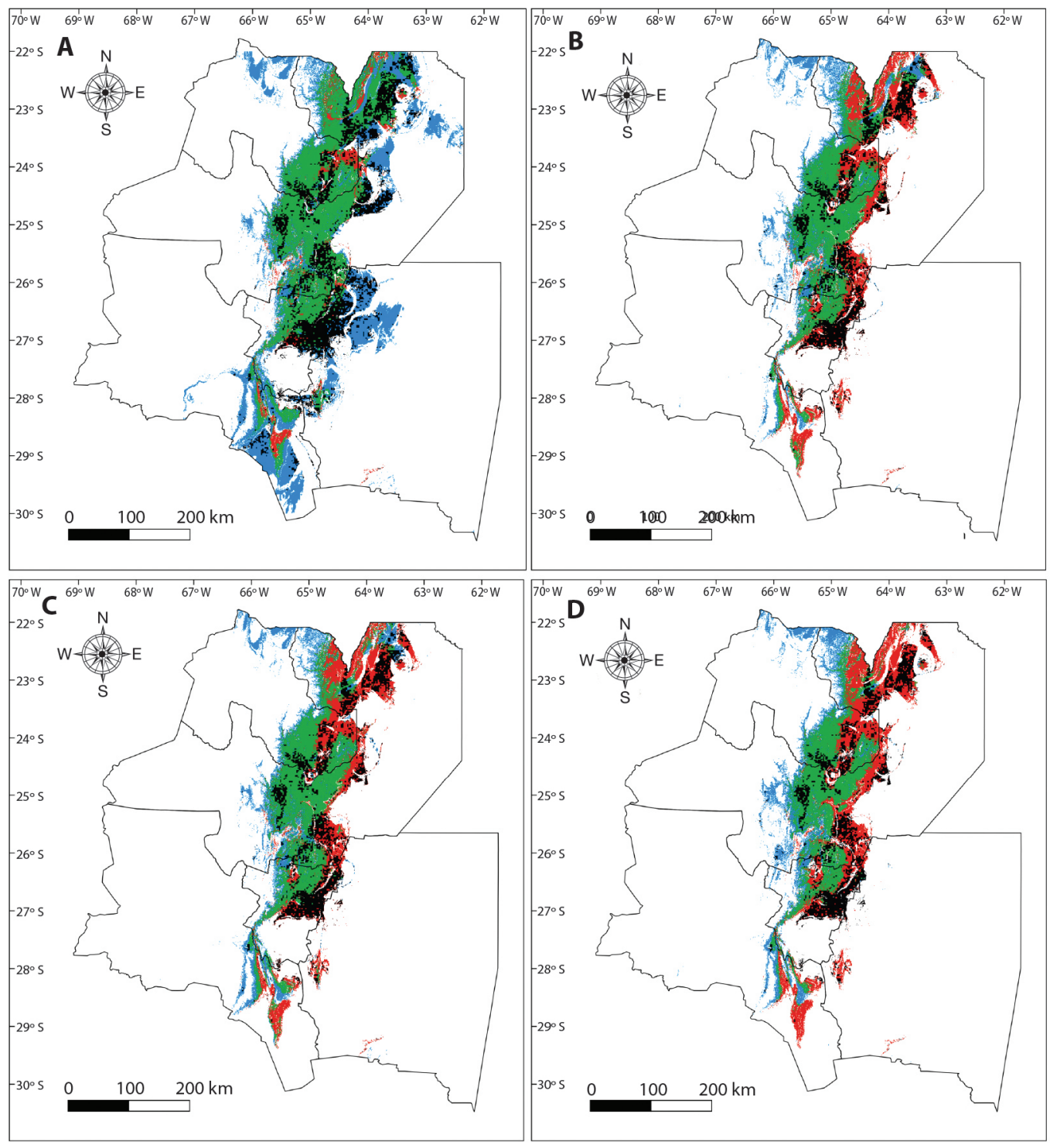

Fig. 4. Synergistic effect of climate change and land use change on A. colubrina future distribution, A. scenario CC2.6, B. scenario CC4.5, C. scenario CC6.0 and D. scenario CC8.5. Green: stable areas, red: retraction areas, and blue: expansion areas, black: lost areas.

of biodiversity loss nowadays, can intensify the adverse effects of climate change, resulting in a more pronounced effect on species distribution range (Travis, 2003). However, there are few studies that investigate the interaction between these two threats using empirical data. As a result, some management strategies could be underestimating the effects of global change and therefore, they could be leading to more relaxed conservation efforts (García-Valdés, Svenning, Zavala, Purves, \& Araújo, 2015; Sirami et al., 2016). Some authors reported that the effects of LUC override the effect of $\mathrm{CC}$; thus, LUC is considered a riskier factor than the $\mathrm{CC}$ for species distribution. In contrast, other authors reported that LUC and 
$\mathrm{CC}$ act synergistically: $\mathrm{CC}$ increases the negative effects on the distribution of the species in a context of fragmentation and habitat loss. In this work, we agree that CC and LUC have a synergistic and negative effect on distribution. We found that a high percentage of the $A$. colubrina distribution range $(47-87 \%)$ would remain stable considering only the $\mathrm{CC}$ effects, while the stable area would be significantly reduced (37-64 \%) if LUC is taken into account too. The loss of distribution area caused by LUC would mainly affect the stable and retraction areas in the different future scenarios. In this context, reforestation and restoration programs could be fundamental to partially mitigate or at least reduce the negative effects of CC (Garcií-Valdes et al., 2015).

In spite SDMs are commonly used worldwide, they can sub or overestimate the distribution range of species, since they do not consider limitations and/or facilitation by dispersion, geographical barriers or species interactions (Phillips et al., 2006; Mateo, Felicisimo, \& Muñoz 2011). Furthermore, models resolution is another factor to consider especially in mountain environments where sudden or pronounced changes can occur in small areas (i.e. altitudinal gradients, exposition, slope) (Franklin et al., 2013). SDMs predictions can also be unrealistic since they consider an instant response to the new climatic conditions. Plant species movements are likely to lag behind broad-scale patterns of climate change over the remainder of this century. Changes in tree species distribution may have a delay from 50 up to 100 years with relation to climate changes. This can be related to the suite of climatically good/bad years for reproduction and establishment, the time to reach reproductive age, changes in dispersal agents, interactions with other species, or fragmentation (Corlett \& Westcott, 2013). Also, the SDMs assume a homogeneous plant response to climate change. They do not consider phenotypic plasticity or intra-specific variability, key aspects to predict species adjustments to the future conditions (Benito-Garzón et al., 2011; Oney, Reineking, O’Neill, \& Kreyling, 2013). This represents a challenge for the generation of new predictive models.

A. colubrina is one of the most representative species of the STDF, therefore it was used to predict the possible responses of these forests in different CC and LUC scenarios. We demonstrated that both processes affect the species distribution and that the synergic effect is higher than the effect of each one alone. This information is useful to plan conservation strategies, to select priority sites to collect germplasm and it is the baseline for future works. A key topic for future research is to know how these changes could influence the life cycle and performance of the species.

Ethical statement: authors declare that they all agree with this publication and made significant contributions; that there is no conflict of interest of any kind; and that we followed all pertinent ethical and legal procedures and requirements. All financial sources are fully and clearly stated in the acknowledgements section. A signed document has been filed in the journal archives.

\section{ACKNOWLEDGMENTS}

We would especially like to thank Mayra Elizabeth Tapia, Isabel Cornejo, Andrea Suares and María Fernanda Crespo for their assistance in fieldwork. This paper was written in the context of the research project "Eco-ethnology: conservation and recovery of cultural and natural biodiversity" (No376/2018), supported by the Research Council of the National University of Salta (CIUNSa) and by the Institute of Ecology and Human Ambient (INEAH). This work is part of a biological science $\mathrm{PhD}$ research entitled "Distribución geográfica, descriptores morfológicos y conservación de Anadenanthera colubrina en el noroeste de Argentina".

\section{RESUMEN}

¿El cambio global modificará la distribución de la planta Anadenanthera colubrina (Fabales: Fabaceae), 
especie clave de los bosques tropicales secos? Introducción: Los Bosques Tropicales Estacionalmente Secos (BTES) son unos de los ecosistemas terrestres más amenazados del planeta como consecuencia del cambio global. Estos bosques albergan una alta biodiversidad y proporcionan una amplia gama de servicios ecosistémicos, por lo que su conservación es una prioridad a nivel mundial. El cambio climático y el cambio en los usos del suelo están afectando la distribución de las especies. Objetivo: El objetivo de este trabajo fue estudiar la distribución potencial de una especie representativa de BTES (Anadenanthera colubrina) en el núcleo del Piedemonte subandino argentino y evaluar los efectos del cambio en los usos del suelo y del cambio climático sobre su distribución. Métodos: La distribución actual y futura de $A$. colubrina fue modelada con Maxent, utilizando 49 puntos de presencia y 20 variables. Los efectos del cambio climático se estimaron en cuatro escenarios que difieren en los niveles de temperatura y concentración de dióxido de carbono. Los efectos del cambio en el uso del suelo se estimaron descontando el área deforestada hasta el 2017 a la distribución actual y futura de la especie. Resultados: La distribución actual de $A$. colubrina representa un $18 \%$ del Noroeste Argentino. Los cambios en el uso del suelo produjeron una disminución del $25 \%$ del área de distribución actual y el cambio climático probablemente causará una retracción al Este y una expansión hacia el oeste y sur de su distribución. El efecto sinérgico del cambio en el uso del suelo y el cambio climático podría producir una pérdida del $63 \%$ considerando el peor escenario de cambio climático. Conclusiones: Nuestros datos demuestran el rol fundamental de los estudios de distribución para evaluar los efectos de las actividades antrópicas. Los cambios en los usos del suelo y el cambio climático podrían tener un efecto negativo y sinérgico sobre la distribución de $A$. colubrina. La posible expansión del núcleo Piedemonte de SDTF hacia el oeste y el sur de la región no estaría limitada por cambios en el uso del suelo, aunque las cadenas montañosas podrían actuar como barreras orográficas y limitar la expansión.

Palabras clave: cambio climático, conservación, rango geográfico, cambios en los usos del suelo, modelos de distribución de especies.

\section{REFERENCES}

Aide, T.M., Grau, H.R., Graesser, J., Andrade-Nuñez, M.J., Aráoz, E., Barros, A.P., \& Peralvo, M. (2019). Woody vegetation dynamics in the tropical and subtropical Andes from 2001 to 2014: satellite image interpretation and expert validation. Global Change Biology, 25, 2112-2126. DOI: $10.1111 /$ gcb.14618

Alibrandi, P., Cardinale, M., Rahman, M.M., Strati, F., Ciná, P., de Viana, M.L., Giamminola, E.M., Gallo, G., Schnell, S., de Filippo, C., Ciaccio, M., \& Puglia, A.M. (2017). The seed endosphere of Anadenanthera colubrina is inhabited by a complex microbiota, including Methylobacterium spp. and Staphylococcus spp. with plant-growth promoting activitie. Plant and Soil, 422, 1-19. DOI: 10.1007/s11104-017-3182-4

Barros, V.R., Boninsegna, J.A., Camilloni, I.A., Chidiak, M., Magrín, G.O., \& Rusticucci, M. (2015). Climate change in Argentina: trends, projections, impacts and adaptation. Wiley Interdisciplinary Reviews: Climate Change, 6, 151-169. DOI: 10.1002/wcc.316

Benito-Garzón, M.B., Alía, R., Robson, T.M., \& Zavala, M.A. (2011). Intra-specific variability and plasticity influence potential tree species distributions under climate change. Global Ecology and Biogeography, 20, 766-778. DOI: 10.1111/j.1466-8238.2010.00646.x

Carod-Artal, F., \& Vásquez-Cabrera, C. (2007). Usos rituales de la semilla de Anadenanthera sp. entre los indígenas sudamericanos. Neurología, 22, 410-415.

Ceballos, G., \& Ortega-Baes, P. (2011). La sexta extinción: la pérdida de especies y poblaciones en el Neotrópico. En J. Simonetti \& R. Dirzo (Eds.), Conservación biológica: perspectivas de Latinoamérica (pp. 95-108). Chile: Editorial Universitaria.

Ciaccio, M., Russo, R., Palla, F., Giamminola, E., \& de Viana, M.L. (2017). A genetic study on subtropical Anadenanthera colubrina (Vell.) Brenan var. cebil (Griseb.) Altschul tree from Northwestern Argentina. Journal of Forest Research, 22(3), 191-194. DOI: 10.1080/13416979.2017.1283975

Corlett, R.T., \& Westcott, D.A. (2013). Will plant movements keep up with climate change? Trends in Ecology and Evolution, 28, 482-488. DOI: 10.1016/j. tree.2013.04.003

Cruz-Cárdenas, G., López-Mata, L., Silva, J.T., BernalSantana, N., Estrada-Godoy, F., \& López-Sandoval, J.A. (2016). Potential distribution model of Pinaceae species under climate change scenarios in Michoacán. Revista Chapingo Serie Ciencias Forestales y del Ambiente, 22, 135-148. DOI: 10.5154/r. rchscfa.2015.06.027

de Viana, M.L., \& Morales Poclava, M.C. (2010). Anta y sus transformaciones territoriales. En F. Lance (Ed.), Desmontar Pizarro (pp. 177-203). Córdoba, Argentina: Mundo Gráfico.

de Viana, M.L., \& Giamminola, E. (2018). Banco de Germoplasma de Especies Nativas del Instituto de Ecología y Ambiente Humano, Universidad Nacional de Salta. Versión 1.3. DOI: 10.15468/rokb5z

Demaio, P., Karlin, U.O., \& Medina, M. (2002). Árboles nativos del centro de Argentina. Buenos Aires, Argentina: Editorial L.O.L.A.

Elith, J., \& Graham, C.H. (2009). Do they? How do they? WHY do they differ? On finding reasons for differing performances of species 
distribution models. Ecography, 32, 66-77. DOI: 10.1111/j.1600-0587.2008.05505.x

Franklin, J., Davis, F.W., Ikegami, M., Syphard, A.D., Flint, L.E., Flint, A.L., \& Hannah, L. (2013). Modeling plant species distributions under future climates: how fine scale do climate projections need to be? Global Change Biology, 19, 473-483. DOI: 10.1111/ gcb. 12051

García-Valdés, R., Svenning, J.C., Zavala, M.A., Purves, D.W., \& Araújo, M.B. (2015). Evaluating the combined effects of climate and land-use change on tree species distributions. Journal of Applied Ecology, 52(4), 902-912.

GBIF. (2018). Anadenanthera colubrina var. cebil (Griseb.). DOI: 10.15468/dl.rszv3g

Gent, P.R., Danabasoglu, G., Marika, L.J., Holland, M., Hunke, C., Jayne, S.R., ... Zhang, M. (2011). The Community Climate System Model Version 4. Journal of Climate, 24, 4973-4991. DOI: 10.1175/2011JCLI4083.1

Guisan, A., \& Thuiller, W. (2005). Predicting species distribution: offering more than simple habitat models. Ecology Letters, 8, 993-1009. DOI: 10.1111/j.1461-0248.2005.00792.x

Hijmans, R.J., Guarino, L., Cruz, M., \& Rojas, E. (2001). Computer tools for spatial analysis of plant genetic resources data: 1. DIVA-GIS. Plant Genetic Resources Newsletter, 127, 15-19.

Hijmans, R.J., Cameron, S.E., Parra, J.L., Jones, P.G., \& Jarvis, A. (2005). Very high resolution interpolated climate surfaces for global land areas. International Journal of Climatology, 25, 1965-1978.

IDEASA. (2018). Infraestructura de datos espaciales de Salta. Monitoreo de desmontes - Período 1976-2017. Retrieved from http://geoportal.idesa.gob.ar

IPCC. (2013). Summary for Policymakers. In: T.F. Stocker, D. Qin, G.-K. Plattner, M. Tignor, S. K. Allen, J. Boschung, A. Nauels, Y. Xia, V. Bex, \& P.M. Midgley (Eds.), Climate Change 2013: The Physical Science Basis. Contribution of Working Group I to the Fifth Assessment Report of the Intergovernmental Panel on Climate Change (pp. 1-27). Cambridge, United: Cambridge University Press.

Leake, A., López, O., \& Leake, M.C. (2016). La deforestación del Chaco Salteño 2004-2015. Salta, Argentina: SMA Ediciones.

Marengo, J.A., Jones, R., Alves, L.M., \& Valverde, M.C. (2009). Future change of temperature and precipitation extremes in South America as derived from the PRECIS regional climate modeling system. International Journal of Climatology: A Journal of the Royal Meteorological Society, 29, 2241-2255. DOI: 10.1002/joc. 1863
Mateo, R., Felicisimo, A.M., \& Muñoz, J. (2011). Modelos de distribución de especies: Una revisión sintética. Revista Chilena de Historia Natural, 84, 217-240.

Miles, L., Newton, A.C., DeFries, R.S., Ravilious, C., May, I., Blyth, S., ... Gordon, J.E. (2006). A global overview of the conservation status of tropical dry forests. Journal of Biogeography, 33, 491-505. DOI: 10.1111/j.1365-2699.2005.01424.x

Mogni, V.Y., Oakley, L.J., Maturo, H.M., Galetti, L.A., \& Prado, D.E. (2015). Biogeografía e florística dos bosques secos estacionais neotropicais. OKARA: Geografia em debate, 9, 275-296.

Monteiro, J., Albuquerque, U., Lins Neto, E., Araújo, E., Albuquerque, M., \& Amorim, E.L.C. (2006). The effects of seasonal climate changes in the caatinga on tannin levels in Myracrodruon urundeuva (Engl.) Fr. All .and Anadenanthera colubrina (Vell.) Brenan. Revista Brasileira Farmacognosia, 16, 338-344. DOI: $10.1590 / \mathrm{S} 0102-695 X 2006000300010$

Naoki, K., Gómez, M.I., López, R.P., Meneses, R.I., \& Vargas, J. (2006). Comparación de modelos de distribución de especies para predecir la distribución potencial de vida silvestre en Bolivia. Ecología en Bolivia, 41, 65-78.

Oney, B., Reineking, B., O’Neill, G., \& Kreyling, J. (2013). Intraspecific variation buffers projected climate change impacts on Pinus contorta. Ecology and Evolution, 3, 437-449.

Paruelo, J.M., Guerschman, J.P., \& Verón, S.R. (2005). Expansión agrícola y cambios en el uso del suelo. Ciencia Hoy, 15, 14-23. DOI: 10.1002/ece3.426

Perea, M.V., Pedraza, G., \& Luceros, J.V. (2007). Relevamiento de flora arbórea autóctona en la provincia de Catamarca. Buenos Aires, Argentina: Consejo Federal de Inversiones.

Perosa, M., Rojas, F., Villagra, P., Tognelli, M.F., Carrara, R., \& Álvarez, J.A. (2014). Distribución potencial de los bosques de Prosopis flexuosa en la Provincia Biogeográfica del Monte (Argentina). Ecología Austral, 24, 238-248.

Phillips, S.J., Anderson, R.P., \& Schapire, R.E. (2006). Maximum entropy modeling of species geographic distributions. Ecological Modelling, 190, 231-259. DOI: 10.1016/j.ecolmodel.2005.03.026

Phillips, S.J., Dudík, M., \& Schapire, R.E. (2020). Maxent software for modeling species niches and distributions (Version 3.4.1). Retrieved from http://biodiversityinformatics.amnh.org/open_source/maxent

Portillo-Quintero, C. \& Sánchez, A. (2010). Extent and Conservation of tropical dry forests in the Americas. Biological Conservation, 143,144-155. 
Portillo-Quintero, C., Sánchez-Azofeifa, A., Calvo-Alvarado, J., Quesada, M., \& do Espirito Santo, M.M. (2015). The role of tropical dry forests for biodiversity, carbon and water conservation in the neotropics: lessons learned and opportunities for its sustainable management. Regional Environmental Change, 15(6), 1039-1049.

Prado, D.E. (2000). Seasonally dry forests of tropical South America: from forgotten ecosystems to a new phytogeographic unit. Edinburgh Journal of Botany, 57, 437-461.

QGIS Development Team. (2019). QGIS Geographic Information System. Open Source Geospatial Foundation Project. Retrieved from http://qgis.osgeo.org

Qin, A., Liu, B., Guo, Q., Bussmann, R.W., Maa, F., Jian, Z., ... Peie, Z. (2017). Maxent modeling for predicting impacts of climate change on the potential distribution of Thuja sutchuenensis Franch., an extremely endangered conifer from southwestern China. Global Ecology and Conservation, 10, 139-146. DOI: 10.1016/j.gecco.2017.02.004

Rodrigues, P.M.S., Silva, J.O., Eisenlohr, P.V., \& Schaefer, C.E.G.R. (2015). Climate change effects on the geographic distribution of specialist tree species of the Brazilian tropical dry forests. Brazilian Journal of Biology, 75, 679-684. DOI: 10.1590/1519-6984.20913

Rudel, T.K. (2017). The dynamics of deforestation in the wet and dry tropics: a comparison with policy implications. Forests, 8(4), 108-120.
Scheldeman, X., \& Van Zonneveld, M. (2011). Manual de Capacitación en Análisis Espacial de Diversidad y Distribución de Plantas. Roma, Italia: Bioversity International.

Sirami, C., Caplat, P., Popy, S., Clamens, A., Arlettaz, R., Jiguet, F., ... Martin, J.L. (2017). Impacts of global change on species distributions: obstacles and solutions to integrate climate and land use. Global Ecology and Biogeography, 26(4), 385-394.

Sunderland, T., Apgaua, D., Baldauf, C., Blackie, R., Colfer, C., Cunningham, A.B, ... Wilmé, L. (2015). Global dry forests: a prologue. International Forestry Review, 17(2), 1-9.

Travis, J.M.J. (2003). Climate change and habitat destruction: a deadly anthropogenic cocktail. Proceedings of the Royal Society of London. Series B: Biological Sciences, 270, 467-473.

Trejo, I., \& Dirzo, R. (2000). Deforestation of seasonally dry tropical forest: a national and local analysis in Mexico. Biological Conservation, 94, 133-142. DOI: 10.1016/S0006-3207(99)00188-3

Verborgh, R., \& De Wilde, M. (2013). Using Open Refine. Packt Publishing Ltd. Retrieved from http://www. openrefine.org

Werneck, F.P., Costa, G.C., Colli, G.R., Prado, D.E., \& Sites Jr, J.W. (2011). Revisiting the historical distribution of Seasonally Dry Tropical Forests: new insights based on palaeodistribution modelling and palynological evidence. Global Ecology and Biogeography, 20, 272-288. DOI: $10.1111 / \mathrm{j} .1466-8238.2010 .00596 . x$ 